International Journal of Agriculture, Environment and Bioresearch

Vol. 4, No. 05; 2019

ISSN: $2456-8643$

\title{
CHANGES IN CHEMICAL PROPERTIES AS INFLUENCED BY TEAK, Tectona grandis PLANTATION ON A TROPICAL SOIL IN AKANGA FOREST RESERVE OF NASARAWA STATE, NIGERIA
}

\author{
Grace Dachung $^{1}$,Bemgba Anjembe ${ }^{2}$ and J.I. Amonum ${ }^{3}$ \\ ${ }^{1 \& 3}$ Department of Forest production and Products, Federal University of Agriculture, Makurdi \\ ${ }^{2}$ Department of Soil Science, Federal University of Agriculture, Makurdi
}

http://doi.org/10.35410/IJAEB.2019.4427

\begin{abstract}
Studies were carried out (Laboratory and field) during the dry and wet seasons of 2010 and 2011 at the Akanga Forest planted with Teak (Tectona grandis) for the production of timber and poles. The area prior to use was an undisturbed forest and planting was carried out from 1966 at an annual interval to the year 1982.The intent of these experiments was to compare the changes in chemical properties of soils at the different age series and to determine the influence of passage of seasons on these properties. Soil samples were collected from three plantation age series 1979, 1980, 1981 and control. The samples were analysed using standard procedures .pH decreased under the plantations and was higher in the dry season. Exchangeable cations recorded higher values under the older age series and were higher in the teak plantations as compared to the natural forests (control). This study showed that rainfall seasons have great effect on the parameters studied .It was concluded that monoculture teak plantations may lead to soil deterioration and consequent reduction in site quality. Monitoring of fast growing exotic monoculture species of younger ages in order to determine the trend of nutrient reduction and the gradual nutrient build-up with increasing plantation age is required.Thus, for a plantation site to be sustainable, there should be no significant negative changes in soil physical, chemical, or biological conditions. In managed forests, the inherent site potential is largely determined by soil characteristics and climatic factors.
\end{abstract}

Keywords: Forest, Teak, Chemical, Properties, Seasons.

\section{INTRODUCTION}

Tectona grandis L.f. (teak) is one of the world's finest hardwoods. Exotic tree species have been found to have effects on soil properties differing from those of indigenous natural forests in terms of organic matter accumulation, soil conditions and type of vegetation growing on the forest floor. Changes in soil properties may either favour an increase in nutrient status of soil or result in deterioration of nutrient status.

There has been a vigorous attempt to introduce exotic species of teak, tectona grandis in Nigeria as viable alternatives to the indigenous sources of poles and timber for industrial uses. However, the effect of these exotic species on the soils and the ecosystem in general have not been well 


\section{International Journal of Agriculture, Environment and Bioresearch}

Vol. 4, No. 05; 2019

ISSN: $2456-8643$

understood. Tectona grandis growth is, however, dependent on site conditions, and relationships have been established between various mineral nutrients, other fertility parameters and moisture of soils and teak growth. The fast growth rates of most plantation tree species and their ability to produce high amounts of biomass within a relatively short period of time have been noted as probable reasons for the continued growth in plantation area. Higher biomass production per unit area has been reported in forest plantation compared to natural forests (Evans 1999; Evans et al., 2004). This high biomass production and fast growth rates of forest plantation species have raised concern about the sustainability of forest plantation sites (Evans 1999; Mishra et al. 1997; Onyekwelu et al. 2006). Thus, for a plantation site to be sustainable, there should be no significant negative changes in soil physical, chemical, or biological conditions. In managed forests, the inherent site potential is largely determined by soil characteristics and climatic factors.

Kurmin Akanga, (Akanga Forest) was first established in 1966 with plantation number FP- PL01-66 in Obi Local Government Area of Nasarawa state .Teak (Tectona grandis) was planted for the production of timber and poles. The area prior to use was an undisturbed forest and planting was carried out at an annual interval to the year 1982.

Since the establishment of this plantation, no effort has been made to consider the effect of the plantation on the physical, chemical and microbial properties and composition of the soils. This research therefore intends to:

i.compare the changes in chemical properties of soil under teak,

ii.determine the soil organic matter accumulation under the tree cover

iii.determine the sustainability of this plantation site

iv.determine the influence of seasons on these properties at the different age series at the Akanga Forest Reserve.

\section{MATERIALS AND METHODS}

The site for the study is an already established plantation of Tectona grandis located in Akanga on Longitude 80 34'E and Latitude 8018 'N within the Guinea Savanna of Nigeria which lies in the central location of the country (Figure 1). The plantation is situated at Akanga in Obi Local Government Area of Nassarawa state.The area fall within the Southern guinea vegetation zone (Keay, 1989). Annual rainfall varies from $1143 \mathrm{~mm}-1397 \mathrm{~mm}$ with the peak occurring in August to September. The area is about $185 \mathrm{~m}$ above sea level.

\section{Site selection and demarcation}

Three age series were considered for sampling based on location and less interference by extraneous factors. Trees planted in the years 1979, 1980 and 1981 with a total hecterage of 78 , 28 and 40 respectively were taken. Plots of $200 \mathrm{~m}$ x $200 \mathrm{~m}$ ware demarcated for sample collection, in each plot 10 soil samples were randomly collected and bulked. Total numbers of plots for the year 1979 were 1,950; 700 plots for 1980 and 1000 plots for 1981. 300 plots were 


\section{International Journal of Agriculture, Environment and Bioresearch}

Vol. 4, No. 05; 2019

ISSN: $2456-8643$

selected for 1979, 110 plots for 1980 and 160 plots for 1981 . Soil samples adjacent to the plantation were also collected as control plots. Soils were collected at the depth of $0-20 \mathrm{~cm}$ using an auger. The sampling was restricted to this zone because it provides the bulk of plant nutrients (Russell et al., 2007).

\section{Laboratory Analysis}

The soil samples were air-dried, crushed and sieved through a $2 \mathrm{~mm}$ sieve for laboratory analᄀysis. The following determinations were carried out using standard procedures: Particle size distribution was estimated by hydrometer method of Bouyoucos 1951. Core samplers were used in taking samples and bulk density was determined and expressed as a weight of dry soil per unit volume of moist soil (Campbell and Henshall, 1991). Total porosity (\%)was computed from those of bulk density value of $2.65 \mathrm{gcm}-3$ (Vomocil, 1965). The soil $\mathrm{pH}$ was measured with a glass electrode in a 1:1 soil-water suspension (Hendershot et al., 1993). Organic Carbon was determined using the wet acid oxidation procedure. (Walkley and Black, 1934). Total Nitrogen was determined by microkjeldahl method as reported by Page et al., 1982. Available Phosphorus was extracted with Bray-1 extractant and the Concentration of $\mathrm{P}$ in the extract was determined colorimetrically (Bray and Kurtz, 1945). Exchangeable bases were extracted using the Melich 3 extractant. $\mathrm{Ca}$ and $\mathrm{Mg}$ were determined by Atomic Absorption Spectrophotometer while $\mathrm{Na}$ and $\mathrm{K}$ were determined using a flame photometer.

\section{RESULTS AND DISCUSSION}

Chemical properties of the experimental sites for the dry season of 2010 are shown in Table 5. $\mathrm{pH}$ of the experimental sites was variable and ranged from 5.80 (moderately acid) at the 1979 plantation, this was followed by 5.90 at the 1980 plantation and 6.02 at the 1981 plantation. The highest $\mathrm{pH}$ value of 6.21 was found at the control.

Percentage $\mathrm{N}$ was also variable with the least value of $0.84 \%$ at the 1980 plantation, this was followed by $0.87 \%$ at the 1979 plantation, and $0.95 \%$ at the control. The highest value of $1.16 \%$ was found at the 1981 plantation.

Percentage Organic Carbon recorded the least value of $6.76 \%$ at the control, followed by $7.66 \%$ at the 1980 plantation, and $8.51 \%$ at the 1981 plantation. The highest value was found at the 1979 plantation with a value of $8.93 \%$.

Available P at the experimental sites was found to be highest at the 1979 plantation with a value of $7.95 \mathrm{ppm}$; this was followed by $7.55 \mathrm{ppm}$ at the 1980 plantation, $6.02 \mathrm{ppm}$ at the 1981 plantation. The least value of Available $\mathrm{P}$ was found at the control with the value of $5.15 \mathrm{ppm}$.

The exchangeable Cations of the experimental locations were variable. Ca content ranged from $3.20 \mathrm{Cmol} / \mathrm{kg}$ at the 1981 plantation, $3.86 \mathrm{Cmol} / \mathrm{kg}$ at the control, $3.96 \mathrm{Cmol} / \mathrm{kg}$ at the 1980 plantation and the highest Value of $4.06 \mathrm{Cmol} / \mathrm{kg}$ was found at the 1979 plantation. Magnesium content recorded the highest value of $1.83 \mathrm{Cmol} / \mathrm{kg}$ at the 1979 plantation, this was followed by $1.73 \mathrm{Cmol} / \mathrm{kg}$ for both control and the 1980 plantation while the highest value of $1.83 \mathrm{Cmol} / \mathrm{kg}$ was found at the 1979 plantation. Potassium content was found to be highest at the control and 
the 1979 plantation with a value of $0.34 \mathrm{Cmol} / \mathrm{kg}$, this was followed by $0.32 \mathrm{Cmol} / \mathrm{kg}$ at the 1980 plantation and $0.26 \mathrm{Cmol} / \mathrm{kg}$ at the 1981 plantation. The values for Sodium content were also variable with the control and 1979 plantation having a value of $0.61 \mathrm{Cmol} / \mathrm{kg}$, followed by the 1980 plantation with a value of $0.60 \mathrm{Cmol} / \mathrm{kg}$ while the least value of $0.46 \mathrm{Cmol} / \mathrm{kg}$ was found at the 1981 plantation.

The Cation Exchange Capacity at the experimental locations was also variable. The least value of $6.76 \mathrm{Cmol} / \mathrm{kg}$ was found at the control, followed by $7.66 \mathrm{Cmol} / \mathrm{kg}$ at the 1980 plantation, $8.51 \mathrm{Cmol} / \mathrm{kg}$ at the 1981 plantation and the highest value of $8.93 \mathrm{Cmol} / \mathrm{kg}$ was recorded at the 1979 plantation.

Table 5: Chemical properties of soil at Akanga Forest Reserve in the dry season of the year 2010

\begin{tabular}{|c|c|c|c|c|c|c|c|c|c|}
\hline \multirow[t]{3}{*}{ Location } & \multirow[t]{3}{*}{$\mathrm{pH}$} & \multirow[t]{3}{*}{$\% \mathrm{~N}$} & \multirow{3}{*}{$\begin{array}{c}\% \\
\text { Org. } \\
\text { C }\end{array}$} & \multirow{3}{*}{$\begin{array}{l}\text { Av.P } \\
\text { (ppm) }\end{array}$} & \multicolumn{4}{|c|}{ Exchangeable } & \multirow{3}{*}{$\begin{array}{c}\mathrm{CEC} \\
(\mathrm{Cmol} / \mathrm{kg})\end{array}$} \\
\hline & & & & & \multirow{2}{*}{\multicolumn{2}{|c|}{$\begin{array}{c}\text { Cations } \\
\qquad \mathrm{Ca}\end{array}$}} & \multicolumn{2}{|c|}{$(\mathrm{Cmol} / \mathrm{kg})$} & \\
\hline & & & & & & & $\begin{array}{l}\mathrm{Mg} \\
\mathrm{Ta}\end{array}$ & K & \\
\hline Control & 6.21 & 0.95 & 6.76 & 5.15 & 3.86 & 1.73 & 0.34 & 0.61 & 6.76 \\
\hline 1979 & 5.80 & 0.87 & 8.93 & 7.95 & 4.06 & 1.83 & 0.34 & 0.61 & 8.93 \\
\hline 1980 & 5.90 & 0.84 & 7.66 & 7.55 & 3.96 & 1.73 & 0.32 & 0.60 & 7.66 \\
\hline 1981 & 6.02 & 1.16 & 8.51 & 6.20 & 3.20 & 1.52 & 0.26 & 0.46 & 8.51 \\
\hline
\end{tabular}

Chemical properties of the experimental sites for the wet season of 2010 are shown in Table 6. The $\mathrm{pH}$ of the experimental sites was variable and ranged from 6.01 at the 1979 plantation, this was followed $\mathrm{pH}$ value of 6.09 at the 1980 plantation and 6.15 at the control and the highest $\mathrm{pH}$ value of 6.21 was found at the 1981 plantation.

Percentage $\mathrm{N}$ at the experimental sites was also variable with the least value of $0.64 \%$ found at the 1979 plantation, followed by $0.77 \%$ found at the 1981 plantation, and $0.81 \%$ recorded at the control. The highest value of $0.88 \%$ was found at the 1980 plantation.

Percentage Organic Carbon recorded the least value of $7.63 \%$ at the 1979 plantation, followed by $7.66 \%$ at the 1980 plantation, and $7.76 \%$ at the control. The highest percentage Organic Carbon was found at the 1981 plantation with a value of $7.84 \%$. 
Vol. 4, No. 05; 2019

ISSN: $2456-8643$

Available $\mathrm{P}$ at the experimental sites was found to be highest at the control with a value of $9.00 \mathrm{ppm}$; this was followed by $6.15 \mathrm{ppm}$ at the 1979 plantation, $6.00 \mathrm{ppm}$ at the 1981 plantation. The least value of Available $\mathrm{P}$ was found at the 1980 plantation with the value of 5.40ppm.

The exchangeable Cations of the experimental locations were variable. Ca content ranged from $2.99 \mathrm{Cmol} / \mathrm{kg}$ at the control, then $3.27 \mathrm{Cmol} / \mathrm{kg}$ at the 1980 plantation, $3.53 \mathrm{Cmol} / \mathrm{kg}$ at the 1981 plantation and the highest value of $3.60 \mathrm{Cmol} / \mathrm{kg}$ was found at the 1979 plantation. Magnesium content recorded the highest value of $1.63 \mathrm{Cmol} / \mathrm{kg}$ at the 1981 plantation, this was followed by $1.61 \mathrm{Cmol} / \mathrm{kg}$ at the 1979 plantation and $1.40 \mathrm{Cmol} / \mathrm{kg}$ at the 1980 plantation while the least value of $1.19 \mathrm{Cmol} / \mathrm{kg}$ was found at the control. Potassium content was found to be highest at the 1981 plantation with a value of $0.31 \mathrm{Cmol} / \mathrm{kg}$, this was followed by $0.30 \mathrm{Cmol} / \mathrm{kg}$ at the 1979 plantation and $0.26 \mathrm{Cmol} / \mathrm{kg}$ at the 1980 plantation and the least value of $0.19 \mathrm{Cmol} / \mathrm{kg}$ was found at the control. The values for Sodium content were also variable with the 1979 and 1981 plantations having a value of $0.44 \mathrm{Cmol} / \mathrm{kg}$, followed by the 1980 plantation with a value of $0.40 \mathrm{Cmol} / \mathrm{kg}$ while the least value of $0.31 \mathrm{Cmol} / \mathrm{kg}$ was found at the control.

The Cation Exchange Capacity at the experimental locations was also variable. The least value of $7.63 \mathrm{Cmol} / \mathrm{kg}$ was found at the 1979 plantation, followed by $7.66 \mathrm{Cmol} / \mathrm{kg}$ at the 1980 plantation, $7.76 \mathrm{Cmol} / \mathrm{kg}$ at the control and the highest value of $7.84 \mathrm{Cmol} / \mathrm{kg}$ was recorded at the 1981 plantation.

Table 6: Chemical properties of soil at Akanga Forest Reserve in the wet season of the year 2010

\begin{tabular}{|c|c|c|c|c|c|c|c|c|c|}
\hline \multirow[t]{2}{*}{$\begin{array}{c}\text { Locatio } \\
\mathrm{n}\end{array}$} & \multirow[t]{2}{*}{$\mathrm{pH}$} & \multirow[t]{2}{*}{$\% \mathrm{~N}$} & \multirow[t]{2}{*}{$\begin{array}{c}\% \text { Org. } \\
\text { C }\end{array}$} & \multirow[t]{2}{*}{$\begin{array}{l}\text { Av.P } \\
\text { (ppm) }\end{array}$} & \multicolumn{4}{|c|}{$\begin{array}{r}\text { Exchangeable } \\
\text { Cations }(\mathrm{Cmol} / \mathrm{kg})\end{array}$} & \multirow[t]{2}{*}{$\begin{array}{c}\mathrm{CEC} \\
(\mathrm{Cmol} / \mathrm{kg})\end{array}$} \\
\hline & & & & & $\mathrm{C}$ & & g & K & \\
\hline Control & 6.15 & 0.81 & 7.76 & 9.00 & 2.99 & $\begin{array}{c}1.1 \\
9\end{array}$ & $\begin{array}{c}0.1 \\
9\end{array}$ & $\begin{array}{c}0.3 \\
1\end{array}$ & 7.76 \\
\hline 1979 & 6.01 & 0.64 & 7.63 & 6.15 & 3.60 & $\begin{array}{c}1.6 \\
1\end{array}$ & $\begin{array}{c}0.3 \\
0\end{array}$ & $\begin{array}{c}0.4 \\
4\end{array}$ & 7.63 \\
\hline 1980 & 6.09 & 0.88 & 7.66 & 5.40 & 3.27 & $\begin{array}{c}1.4 \\
0\end{array}$ & $\begin{array}{c}0.2 \\
6\end{array}$ & $\begin{array}{c}0.4 \\
0\end{array}$ & 7.66 \\
\hline 1981 & 6.21 & 0.77 & 7.84 & 6.00 & 3.53 & $\begin{array}{c}1.6 \\
3\end{array}$ & $\begin{array}{c}0.3 \\
1\end{array}$ & $\begin{array}{c}0.4 \\
4\end{array}$ & 7.84 \\
\hline
\end{tabular}


International Journal of Agriculture, Environment and Bioresearch

Vol. 4, No. 05; 2019

ISSN: $2456-8643$

Chemical properties of the experimental sites for the dry season of the second year of study 2011 are shown in Table 7. The soil $\mathrm{pH}$ of the experimental sites was found to range from 5.55 at the 1980 plantation, this was followed $\mathrm{pH}$ value of 5.98 at the 1979 plantation and 5.99 at the 1981 plantation and the highest $\mathrm{pH}$ value of 6.11 was found at the control.Percentage $\mathrm{N}$ at the experimental sites was variable with the least value of $0.88 \%$ found at the control, followed by $0.91 \%$ found at the 1980 plantation, and $0.97 \%$ recorded at the 1979 plantation. The highest value of $0.99 \%$ was found at the 1981 plantation. Percentage Organic Carbon recorded the least value of $7.44 \%$ at the control, followed by $8.50 \%$ at the 1980 plantation, and $8.72 \%$ at the 1979 plantation. The highest percentage Organic Carbon was found at the 1981 plantation with a value of $8.78 \%$. While the Organic Matter content recorded the highest value of 1.67 at the 1979 plantation followed by 1.61 at the control, 1.55 at the 1980 plantation and the least value 1.48 found at the 1981 plantation. $\mathrm{P}$ at the experimental sites was found to be variable at the experimental sites with the highest value $9.00 \mathrm{ppm}$ found at the 1979 plantation, this was followed by $7.90 \mathrm{ppm}$ at the 1981 plantation, $7.40 \mathrm{ppm}$ at the 1979 plantation. The least value of Available $\mathrm{P}$ was found at the control with the value of $6.88 \mathrm{ppm}$. The exchangeable Cations of the experimental locations were variable. Ca content ranged from $3.18 \mathrm{Cmol} / \mathrm{kg}$ at the control, then $4.00 \mathrm{Cmol} / \mathrm{kg}$ at the 1979 and 1980 plantations, the highest value of $4.11 \mathrm{Cmol} / \mathrm{kg}$ was found at the 1981 plantation. Magnesium content recorded the highest value of $1.82 \mathrm{Cmol} / \mathrm{kg}$ at the 1981 plantation, this was followed by $1.81 \mathrm{Cmol} / \mathrm{kg}$ at the 1980 plantation and $1.74 \mathrm{Cmol} / \mathrm{kg}$ was found at the 1979 plantation while the least value of $1.66 \mathrm{Cmol} / \mathrm{kg}$ was found at the control. Potassium content was found to be highest at the 1979 plantation with a value of $0.34 \mathrm{Cmol} / \mathrm{kg}$, this was followed by $0.33 \mathrm{Cmol} / \mathrm{kg}$ at the 1980 plantation and $0.32 \mathrm{Cmol} / \mathrm{kg}$ was found at the 1981 plantation, while the least value of $0.31 \mathrm{Cmol} / \mathrm{kg}$ was found at the control. The values for Sodium content were also variable with control having the least value of $0.55 \mathrm{Cmol} / \mathrm{kg}$, followed by the 1981 plantation with a value of $0.56 \mathrm{Cmol} / \mathrm{kg}$ and $0.60 \mathrm{Cmol} / \mathrm{kg}$ was recorded for the 1979 plantation while the highest value of $0.61 \mathrm{Cmol} / \mathrm{kg}$ was found at the 1980 plantation.

The Cation Exchange Capacity at the experimental locations was also variable. The least value of $8.50 \mathrm{Cmol} / \mathrm{kg}$ was found at the 1980 plantation, followed by $8.72 \mathrm{Cmol} / \mathrm{kg}$ at the 1979 plantation, $8.78 \mathrm{Cmol} / \mathrm{kg}$ at the 1981 plantation and the highest value of $9.12 \mathrm{Cmol} / \mathrm{kg}$ was recorded at the control. 
International Journal of Agriculture, Environment and Bioresearch

Vol. 4, No. 05; 2019

ISSN: $2456-8643$

Table 7: Chemical properties of soil at Akanga Forest Reserve in the dry season of the year 2011

\begin{tabular}{|c|c|c|c|c|c|c|c|c|c|}
\hline \multirow[t]{2}{*}{ Location } & \multirow[t]{2}{*}{$\mathrm{pH}$} & \multirow[t]{2}{*}{$\% \mathrm{~N}$} & \multirow{2}{*}{$\begin{array}{c}\% \\
\text { Org. } \\
\text { C }\end{array}$} & \multirow[t]{2}{*}{$\begin{array}{l}\text { Av.P } \\
\text { (ppm) }\end{array}$} & \multicolumn{4}{|c|}{$\begin{array}{r}\text { Exchangeable } \\
\text { Cations }(\mathrm{Cmol} / \mathrm{kg})\end{array}$} & \multirow[t]{2}{*}{$\begin{array}{c}\mathrm{CEC} \\
(\mathrm{Cmol} / \mathrm{kg})\end{array}$} \\
\hline & & & & & $\mathrm{Ca}$ & $\mathrm{Mg}$ & $\mathrm{K}$ & $\mathrm{Na}$ & \\
\hline Control & 6.11 & 0.88 & 7.44 & 6.88 & 3.18 & 1.66 & 0.31 & 0.55 & 9.12 \\
\hline 1979 & 5.98 & 0.97 & 8.72 & 7.40 & 4.00 & 1.74 & 0.34 & 0.60 & 8.72 \\
\hline 1980 & 5.55 & 0.91 & 8.50 & 9.00 & 4.00 & 1.81 & 0.33 & 0.61 & 8.50 \\
\hline 1981 & 5.99 & 0.99 & 8.78 & 7.90 & 4.11 & 1.82 & 0.32 & 0.56 & 8.78 \\
\hline
\end{tabular}

Chemical properties of the experimental sites for the wet season of the second year of study 2011 are shown in Table 8. The soil $\mathrm{pH}$ of the experimental sites was variable and ranged from 5.58 at the control, this was followed $\mathrm{pH}$ value of 5.77 at the 1980 plantation and 5.84 at the 1979 plantation and the highest $\mathrm{pH}$ value of 6.20 was found at the 1981 plantation.Percentage $\mathrm{N}$ at the experimental sites was also variable with the least value of $0.76 \%$ found at the 1979 plantation, followed by $0.83 \%$ found at the 1981 plantation, and $0.84 \%$ recorded at the control. The highest value of $0.87 \%$ was found at the 1980 plantation. Percentage Organic Carbon was found to have the least value of $7.84 \%$ at the 1979 plantation, followed by $7.95 \%$ at the 1980 plantation, and $8.16 \%$ at the 1981 plantation while the highest value of $8.32 \%$ was found for the control. While the Organic Matter content recorded the highest value of 1.41 at the 1979 plantation, followed by 1.00 at the control and $0.92 \%$ at the 1980 plantation while the least value of 0.88 was found for the 1981 plantation.Available $\mathrm{P}$ at the experimental sites was found to be variable, with the highest value of $9.00 \mathrm{ppm}$ found at the 1980 plantation, this was followed by $7.40 \mathrm{ppm}$ for both the 1979 and 1981 plantations. The least value of $6.88 \mathrm{ppm}$ was found at the control.The exchangeable Cations of the experimental locations were variable. Ca content ranged from 3.13 $\mathrm{Cmol} / \mathrm{kg}$ at the 1980 plantation, followed by $3.17 \mathrm{Cmol} / \mathrm{kg}$ at the 1981 plantation, $3.24 \mathrm{Cmol} / \mathrm{kg}$ at the control and the highest value of $3.30 \mathrm{Cmol} / \mathrm{kg}$ was found at the 1979 plantation. Magnesium content recorded the highest value of $1.51 \mathrm{Cmol} / \mathrm{kg}$ at the 1979 plantation, this was followed by $1.45 \mathrm{Cmol} / \mathrm{kg}$ at the 1981 plantation and $1.41 \mathrm{Cmol} / \mathrm{kg}$ at the control while the least value of $1.29 \mathrm{Cmol} / \mathrm{kg}$ was found at the 1980 plantation. Potassium content was found to be highest at the 1979 plantation with a value of $0.27 \mathrm{Cmol} / \mathrm{kg}$, this was followed by $0.25 \mathrm{Cmol} / \mathrm{kg}$ at the 1981 plantation and $0.22 \mathrm{Cmol} / \mathrm{kg}$ at the 1980 plantation and the least value of $0.21 \mathrm{Cmol} / \mathrm{kg}$ was found at the control. The values for Sodium content were also variable with the 1979 plantation having the highest value of $0.41 \mathrm{Cmol} / \mathrm{kg}$, followed by the control with a 
Vol. 4, No. 05; 2019

ISSN: $2456-8643$

value of $0.39 \mathrm{Cmol} / \mathrm{kg}$ and $0.37 \mathrm{Cmol} / \mathrm{kg}$ found at the 1981 plantation while the least value of $0.34 \mathrm{Cmol} / \mathrm{kg}$ was found at the 1980 plantation.

The Cation Exchange Capacity at the experimental locations was also variable. The least value of $7.84 \mathrm{Cmol} / \mathrm{kg}$ was found at the 1979 plantation, followed by $7.95 \mathrm{Cmol} / \mathrm{kg}$ at the 1980 plantation, $8.16 \mathrm{Cmol} / \mathrm{kg}$ at the 1981 plantation and the highest value of $8.32 \mathrm{Cmol} / \mathrm{kg}$ was recorded at the control.

Table 8: Chemical properties of soil at Akanga Forest Reserve in the wet season of the year 2011

\begin{tabular}{|c|c|c|c|c|c|c|c|c|c|}
\hline \multirow[t]{2}{*}{$\begin{array}{c}\text { Locatio } \\
n\end{array}$} & \multirow[t]{2}{*}{$\mathrm{pH}$} & \multirow[t]{2}{*}{$\% \mathrm{~N}$} & \multirow[t]{2}{*}{$\begin{array}{c}\% \text { Org. } \\
\text { C }\end{array}$} & \multirow[t]{2}{*}{$\begin{array}{l}\text { Av.P } \\
\text { (ppm) }\end{array}$} & \multicolumn{4}{|c|}{$\begin{array}{l}\text { Exchangeable Cations } \\
(\mathrm{Cmol} / \mathrm{kg})\end{array}$} & \multirow[t]{2}{*}{$\begin{array}{c}\text { CEC } \\
(\mathrm{Cmol} / \mathrm{kg})\end{array}$} \\
\hline & & & & & $\mathrm{Ca}$ & & Ig & K & \\
\hline Control & 5.58 & 0.84 & 8.32 & 6.88 & 3.24 & 1.41 & 0.21 & $\begin{array}{c}0.3 \\
9\end{array}$ & 8.32 \\
\hline 1979 & 5.84 & 0.76 & 7.84 & 7.40 & 3.30 & 1.51 & 0.27 & $\begin{array}{c}0.4 \\
1\end{array}$ & 7.84 \\
\hline 1980 & 5.77 & 0.87 & 7.95 & 9.00 & 3.13 & 1.29 & 0.22 & $\begin{array}{c}0.3 \\
4\end{array}$ & 7.95 \\
\hline 1981 & 6.20 & 0.83 & 8.16 & 7.40 & 3.17 & 1.45 & 0.25 & $\begin{array}{c}0.3 \\
7\end{array}$ & 8.16 \\
\hline
\end{tabular}

In the present study $\mathrm{pH}$ decreased under the plantations. Soil $\mathrm{pH}$ under trees generally decreased as a result of organic acids released by decomposing litters and exchangeable cation uptake. Similar decrease in soil pH was observed by Russell et al. (2007), which were attributed to advanced weathering of the soil and cation storage by tree biomass.

High surface nutrient contents was also reported by Owusu-Bennoah et al. (2000), which wasascribed to the ion - pump effects of vegetation. Similar results have been observed by 


\section{International Journal of Agriculture, Environment and Bioresearch}

Vol. 4, No. 05; 2019

ISSN: $2456-8643$

Chaubey et al., (1987), who observed a decrease in soil $\mathrm{pH}$ under teak plantations compared with soil under adjoining natural forest. These workers also observed that $\mathrm{pH}$ under both areas decreased with increasing age of plantation. A decrease in soil $\mathrm{pH}$ has also been observed under teak plantations as compared with adjoining natural forest dominated by Dipterocarpus . Chaubey et al., (1987) observed that the $\mathrm{pH}$ in soil under plantation monocultures varied depending on the intrinsic $\mathrm{pH}$ of the soil and the type of tree species growing on the site.

Soil organic carbon is directly related to soil fertility in that it is the organic carbon present in soil that is eventually converted to nitrate for plant uptake (Unanaonwi, 2009). This implies that the more the organic carbon contents of a soil, the more the nitrogen content of the soil, and the more fertile the soil will be.

Results from the study reveals that, Percentage Organic Carbon was highest (8.93\%) in soils under the 1979 plantation as compared to the control plots (6.76\%). Turner and Lambert (2000) found that soil organic $\mathrm{C}$ under Pinus was lower than that under adjacent native forest. In a chronosequence study under $P$. radiata and $E$. grandis, Turner and Lambert (2000) observed an ongoing decline in soil organic carbon for 12 years; thereafter, soil $\mathrm{C}$ stabilized and increased nearly age 20 years. Paul et al., (2002) reviewed 43 published studies, and noted a soil $\mathrm{C}$ decline of $3.46 \%$ per year following afforestation; however, when plantations were established on excropped land in tropical and subtropical regions, an accumulation of soil $\mathrm{C}$ was observed. Hartemink (2003), also looking at cross-country studies of tropical regions found either a decline or increase in soil attributes depending on stand types including Pinus, Eucalyptus, Acacia, and Casuarina genera. Therefore, we conclude that carbon sequestration in forest soils is markedly variable depending on tree species, soil type, and climate.

Chaubey et al., (1987) reported that Teak plantations had significantly higher $M g$ and $K(B$ horizon) and $\mathrm{Ca}$ (O/A horizon) concentrations than the undisturbed forest. This trend suggests that exchangeable base concentrations increase when land use changes from undisturbed forest to pasture, then pasture to plantation, with the most pronounced effect of this in teak plantations exhibiting more high fertility plots than other land uses. Soil organic carbon concentration was similar for all land uses except for a significantly lower concentration in teak plantations than in active pasture (O/A horizons). These results suggest that teak plantations may be advantageous for increasing soil fertility but, with respect to restoration of undisturbed forest conditions, present significant deviations in soil chemistry.

Belsky (1994) also reported higher levels of organic matter for the soil under the canopy of Acaciatortilis in semi-arid savanna in East Africa than in open grassland. Pandey (1983) observed that organic matter was higher under the canopies of Acacia nilotica in India, while Young (1997), who reviewed several studies, reported a significant build-up of organic matter under the canopies of various trees, including Albizia saman, Adansonia digitata, Parkia biglobosa and Faidherbia albida.

Percentage $\mathrm{N}$ was variable during the study period, highest value of 1.16 was found under the 1981 plantation in the dry season and 0.88 was recorded in the 1980 plantation during the wet season. Generally, the least values for this parameter were obtained at the control. Nitrogen accounts for up to $3 \%$ of all plant compounds. It is the most abused and misused production input in growing crops. The key to reducing nitrogen growing costs is to reduce nitrogen losses. The present nitrogen recommendations in most growing situations are based upon experience 
and are usually in excess of specific plant requirements. Nitrogen losses come about by reduced aeration and higher compaction in soil. Nitrates can be lost by being converted to gaseous nitrogen by anaerobic microorganisms in soils. Higher total $\mathrm{N}$ in the natural forest's top soil layers as compared with plantations of fast-growing species has been reported elsewhere (Chaubey et al., 1987) and may be related to higher demand and uptake of $\mathrm{N}$ by young teak. The slightly higher total $\mathrm{N}$ in the natural forests may also be attributable to their greater species diversity of vegetation cover and presence of more organic matter (Lundgren 1978, Maro et al., 1993). Similar results have been observed in Madhadya Pradesh, India (Chaubey et al 1987).

When phosphorus intake is deficient, plants will produce red and purple leaf colors and exhibit stunted root and top growth. Most synthetic phosphate fertilizers, when added to the soil, undergo a degree of phosphate fixation with other soil elements. The degree of fixation depends upon the chemical nature of the soil. High sodium levels reduce phosphorus availability. Bioorganic phosphates are chelated in organic complexes and designed to favour microbiological activity that converts phosphorus to a more available form for plant use, thereby, preventing losses by fixation. In the present study, Available $\mathrm{P}$ at the experimental sites was found to be variable, with the highest values recorded in the plantation. The least value was found at the control. Increased availability of $\mathrm{P}$ has been observed under the teak plantations than under adjoining natural forests (Chaubey et al., 1987) and under Gmelina arborea plantation as compared to lowland natural forests (Egunjobi 1991). In contrast several workers have reported a decrease in available P in teak plantations than natural forests. Decrease in available P in teak plantations may be indicative of higher $\mathrm{P}$ uptake by teak and immobilisation within young and semimature teak biomass. Decrease in available P may also be due to cutting natural forest and burning during site preparation and occasional fires in teak plantations. Egunjobi (1991) suggested that cutting and burning of forests result in quick scarcity of $\mathrm{P}$ in tropical soils due to destruction of mechanism of $\mathrm{P}$ mobilisation when the natural forest is cut and burned. Decrease in available $\mathrm{P}$ in broad-leaved tree plantations as compared to natural forests has been observed in Nigeria (Adejuwon \& Ekanode 1988). Egunjobi 1991 observed that Bray's P decreased when virgin tropical rain forests were replaced by plantation crops including teak. Decrease in available $\mathrm{P}$ has also been observed in Cupressus lusitanica plantations in Kenya (Robinson 1967), under Pinus caribaea and cocoa plantations in Nigeria (Egunjobi 1991), and under teak plantations in Tamil Nadu in India (Prasad et al., 1985) as compared to natural forests.

The exchangeable Cations of the experimental locations were variable. Ca content ranged from $3.13 \mathrm{Cmol} / \mathrm{kg}$ at the 1980 plantation, followed by $3.17 \mathrm{Cmol} / \mathrm{kg}$ at the 1981 plantation, 3.24 $\mathrm{Cmol} / \mathrm{kg}$ at the control and the highest value of $3.30 \mathrm{Cmol} / \mathrm{kg}$ was found at the 1979 plantation. Magnesium content recorded the highest value of $1.51 \mathrm{Cmol} / \mathrm{kg}$ at the 1979 plantation, this was followed by $1.45 \mathrm{Cmol} / \mathrm{kg}$ at the 1981 plantation and $1.41 \mathrm{Cmol} / \mathrm{kg}$ at the control while the least value of $1.29 \mathrm{Cmol} / \mathrm{kg}$ was found at the 1980 plantation. Potassium content was found to be highest at the 1979 plantation with a value of $0.27 \mathrm{Cmol} / \mathrm{kg}$, this was followed by $0.25 \mathrm{Cmol} / \mathrm{kg}$ at the 1981 plantation and $0.22 \mathrm{Cmol} / \mathrm{kg}$ at the 1980 plantation and the least value of $0.21 \mathrm{Cmol} / \mathrm{kg}$ was found at the control. The values for Sodium content were also variable with the 1979 plantation having the highest value of $0.41 \mathrm{Cmol} / \mathrm{kg}$, followed by the control with a value of $0.39 \mathrm{Cmol} / \mathrm{kg}$ and $0.37 \mathrm{Cmol} / \mathrm{kg}$ found at the 1981 plantation while the least value of $0.34 \mathrm{Cmol} / \mathrm{kg}$ was found at the 1980 plantation. Study of a 28 -year-old even-aged contiguous 
monocultures located in the lowland rain forest belt of southwestern Nigeria, consisting of teak, idigbo (Terminalia ivorensis), opepe (Nauclea diderrichii) and gmelina (Gmelina arborea) revealed significant losses in soil calcium and available phosphorus (Okoro et. al., 2000). However, the effective cation exchange capacity and magnesium contents of the soils were not affected by plantation activities.

The Cation Exchange Capacity at the experimental locations was also variable. The least value of $7.84 \mathrm{Cmol} / \mathrm{kg}$ was found at the 1979 plantation, followed by $7.95 \mathrm{Cmol} / \mathrm{kg}$ at the 1980 plantation, $8.16 \mathrm{Cmol} / \mathrm{kg}$ at the 1981 plantation and the highest value of $8.32 \mathrm{Cmol} / \mathrm{kg}$ was recorded at the control.

In general, however, there was an increase in exchangeable cations in the teak plantations as compared to the natural forests (control). G. arborea, Egunjobi 1991 also observed that exchangeable $\mathrm{K}, \mathrm{Ca}$, and $\mathrm{Mg}$ increased compared with natural forests. Chaubey et al., (1987) observed that exchangeable $\mathrm{K}$ was higher under teak plantations than under adjoining natural forests. Results of the present study and those in the literature show that the effect of plantation forests on soil differ from one geographical region to another when the same tree species is involved. Some reasons which may explain these differences have been summarized Peng et al., (2004).

The soil $\mathrm{pH}$ over the seasons was higher in the dry season this might be attributed to the little rainfall and probably due to the bush burning occurring between December and January which is an annual occurrence in the savanna woodland, while the ash released from the accumulated litter following burning in January, caused a slight rise in the soil $\mathrm{pH}$. In the same vein, the dissolution of the ash after early rains in May could be the major reason for slight increase in soil pH (Fatubarin and Olojugba, 2014).

Nitrogen is easily lost from system during an intense fire, as it volatilizes at temperatures as low as $200^{\circ} \mathrm{C}$ (White et al., 1973) which could probably be the reason for the low Nitrogen content in the dry season and also through increased leaching of Nitrates during early rains as a result of the absence of vegetation cover, while the increased Nitrogen content could be attributed to the increase in activity of nitrogen fixing microbes (Zeng et al., 2009). Evidence also exist that increased biological nitrogen fixation along with increased mineralization rates occur during the wet season which has resulted in increased Nitrogen content at this time (Zeng et al., 2009).

During the wet season, the exchangeable bases (calcium, magnesium, potassium, sodium) were low and this could be attributed to these elements being utilized by the regenerating plants, since these are reputed for their vigorous regeneration and growth following annual fires (Hopkins, 1974). Considering the importance of these elements in tissues synthesis, there are enough indications to show that the disappearance of these elements could be due to the synthesis of plant tissues in newly flushing suckerings and sprouts from the plants of the herbaceous layer and possibly the flowers of ligneous savanna plants (Hopkins, 1974). At the end of rains, however, the vigorous tree growth might have been decreased which accounted for high exchange bases. 


\section{International Journal of Agriculture, Environment and Bioresearch}

Vol. 4, No. 05; 2019

ISSN: 2456-8643

A large portion of the nutrient reserve in most forest ecosystems is contained in the organic material on the forest floor (Wagner et al., 2004). While the decrease might be attributed to the growth of plants and accumulation of biomass during growing season (Styles and Coxon, 2007).

The increased cations exchange capacity during the dry season might be due to condusive environmental conditions which favour rapid decomposition of dead plant materials that lead to accumulation of soil organic matter (Fatubarin, 1980).

It was observed that there were decline in the soil nutrients during the wet season, which also coincided with the active growth period of forest trees. Therefore, the limitation of $\mathrm{N}, \mathrm{P}, \mathrm{Ca}, \mathrm{Mg}$, $\mathrm{K}$, to tree growth is most likely to occur (Chen et al., 2003). Protection of the litter layer is strongly recommended to ameliorate soil degradation and nutrient limitation in the study area, since litter layer was not only the main source of soil organic matter and available nutrients, but also the regulator of soil microbial activity (Chen et al., 2003).

Teak is a calcicolous species and requires a relatively large amount of soil $\mathrm{Ca}$ for its growth and development (White 1991, Tewari 1992). Of the various mineral elements needed in adequate quantities for the proper development of teak, $\mathrm{Ca}$ is regarded as the most important for regulating physiology (Bebarta 1999). In particular, the amount of nutrient uptake by young teak trees is much more than the amount of nutrients returned to the soil. According to George and Buvaneswaran (2001), about 75-85\% of nutrients absorbed from soil were retained in two-yearold teak stands and only $15-25 \%$ of nutrients were returned to the soil. However, they also observed that about $66-77 \%$ of nutrients absorbed in 20 - year-old teak plantations were returned to the soil.

It was concluded that there were changes in chemical properties of soil under teak, these changes were significant and resulted into nutrient accumulation as well as soil organic matter. The plantation is thus sustainable. The seasons had profound influence on the soil properties at the different age series

\section{REFERENCES}

Bebarta, K. C. 1999. Teak: Ecology, Silviculture, Management and Profitability. International Book Distributors,Dehra Dun.

Belsky, A.J. (1994) Influence of trees on savanna productivity: tests of shade, nutrients and treegrass competition. Ecology, 75, 922-932.

Bouyoucos, G.J (1951): Hydrometer method for making particle size analysis of soils. Soil science society of America proceedings. 26, 464-465.

Bray, R.H.; Kurtz, L.T., 1945. Determination of total organic and available forms of Phosphorus in soils. Soil Sc. 59:39-45.

Campbell, D.J and Henshall, J.K (1991): Bulk Density: In Soil Analysis Physical Methods. Smith KA, Mullins CE eds Marcel Dekker New York 329-366. 
Chaubey, O. P., Ram Prasad and Mishra, G. P. 1988. Litter production and nutrient return in teak plantations and adjoining natural forests in Madhya Pradesh. Journal of Tropical Forestry. 4: 242-255.

Egunjobi, J.K. (1991). Litterfall and mineralization in a Teak (Tectona grandis) stand. Oikos 25: 222-6.

Evans J (1999): Planted forests of the wet and dry tropics: their variety, nature and significance. New Forests. 17: 25-36.

Evans J, Turnbull JW (2004). Plantation Forestry in the Tropics. Oxford University Press, New York, NY, USA, pp. 482.

Hartemink A.E (2003): Soil fertility decline in the tropics with case studies on plantations. CABI, London, UK, p. 360.

Hendershort WH, Lalande H, Duquette M (1993). Soil reaction and exchangeable acidity. In; Soil Sampling and Methods of Analysis (ed. M.R. Carter). Lewis publishers, USA. pp. 141-149.

Hopkins, B. (1974). Forest and Savanna burning in Olokemeji Forest reserve, Nigeria J. Appl. Ecol. 2:367-381.

Keay, R. W. J. (1989). Trees of Nigeria. Clarendon Press Oxford.

Mishra, D.M.,Mishra, T.K. and Banerjee,S.K.,1997, Comparative phyto-sociological and soil physicochemical aspects between managed and unmanaged alteritic land. Annals of forestry,

(1):16-25.

Okoro, S.P.A._ Aighewi, I. T. and Osagie, C. O. 1999. Effects of selected monoculture plantation species on the humid tropical soils of Southern Nigeria. Nigerian Journal Forestry, 29: 73-79.

Okoro, S. P. A., Aighewi, 1. T. and Osagie, C. O. 2000. Effects of selected monoculture plantation species on the humid tropical soils of southern Nigeria. Indian Journal of Agricultural Science, 70: 105-109.

Onyekwelu J.C, Mosandl R, Stimm B (2006): Productivity, site evaluation and state of nutrition of Gmelina arborea plantations in Oluwa and Omo forest reserves, Niger. For. Ecol. Manage. 229: 214- 227.

Owusu-Bennoah, E.,T.W. Awadzi, E. Boateng, L. Krogh, H. Breuning-Madson and O.K. Borggaard, 2000. Soil properties of a toposequence in the moist semideciduous forest of Ghana West Africa. J. App. Eco., 1: 1-10.

Page, A. I.., Miller, R. I--1. and Keeney, D. R. 1982. Methods of Soil Analysis. Part 1l. American Society ol'Agronomy. lnc., Madison, Wisconsin, USA. 728p.

Pandey, D. 1983. Growth and yield of plantation species in the tropics. FAO Rome 115 pp. 
Paul, K. I., Polglase, P. J., Nyakuengama, J. G. \& Khanna, P. K. 2002. Change in soil carbon following afforestation. Forest Ecology and Management 168: 241-257.

Peng C, Liu J, Dang Q, Apps MJ, Jiang H (2002) TRIPLEX: a generic hybrid model for predicting forest growth and carbon and nitrogen dynamics. Ecol Model 153:109-130

Perez, C.A., Armesto, J.J., Torrealba, C. and Carmona, M.R. (2003): Litterfall dynamics and nitrogen use efficiency in two evergreen tropical rainforests of southern Chile. Austral Ecology. 28, 591- 600 .

Russell, A.E., J.W. Raich, O. J. Valverde-Barrentes and R.F. Fisher, 2007. Tree Species effects on soil properties in Experimental Plantation in Tropical Moist Forest. Soil Sci. Am., 71(4).

Styles D, Coxon C. (2007). Meteorological and management influences on seasonal variations in phosphorous fractions extracted from soils in western Ireland, Geoderma 142:52-164.

Unanaonwi, O.E., 2009b. Acidity, Organic carbon and Nitrogen status of soils under Acacia senegal L. (Willd.) Plantation and Natural forest in Gummi forest reserve, Zamfara State, Nigeria. Nigerian Journal of Forestry, Vol.38 (2): 91-99 20.

Walkley, A. and I.A. Black, (1934). An examination of the Degtgreft method for determining soil organic matter and a proposed modification of chronic acid titration method. Soil Sci., 34:29-38.

Weaner, P.L.; Bindsay, R.A. and Lugo, A.E. (1987). Soil Organic Matter in Secondary Forest in Puerto Rico. Biotropica 19(1): 17-23.

Young, A. (1997) Agroforestry for Soil Management. CAB International, Wallingford, UK.

Zeng DH, Hu YL, Chang SX, Fan ZP (2009). Land cover change effects on soil chemical and biological properties after planting Mongolian pine (Pinus sylvestris var. mongolica) in sandy lands in Keerqin, northeastern China. Plant and Soil 317:121-133. 